\title{
P.P. Согуйко
}

Львівський наџіональний медичний університет імені Данила Галицького

\section{ПОРІВНЯННЯ ПОСТТРАВМАТИЧНОЇ ДИНАМІКИ ЩІЛЬНОСТІ КІСТКОВОЇ ТКАНИНИ НИЖНЬОЇ ЩЕЛЕПИ У ІНТАКТНОГО ЩУРА ТА НА ТЛІ ТРИВАЛОГО ВЖИВАННЯ НАЛБУФІНУ}

Резюме. Щільність кісткової тканини є універсальним показником, що дозволяє визначити ії якість, оцінити і спрогнозувати ранні кількісно-якісні зміни та простежити їх динаміку в клінічних і експериментальних умовах. Метою нашого дослідження стало з'ясування закономірностей посттравматичної динаміки щільності кісткової тканини нижньої щелепи після нанесення кісткоруйнуючої травми інтактним тваринам та тваринам, які впродовж тривалого часу вживають налбуфін. Дослідження виконане на 20 статевозрілих безпородних щурах-самцях масою тіла 180-200 г та віком 3,5 місяці. Дослідних тварин утримували в умовах віварію Львівського національного медичного університету імені Данила Галицького. Усі дослідження проводилися відповідно до положень Європейської конвенції щодо захисту хребетних тварин, яких використовують в експериментальних та інших наукових цілях (Страсбург, 1986), Директиви Ради Європи 86/609/EЕC (1986), Закону України № 3447-IV «Про захист тварин від жорстокого поводження». Травму моделювали шляхом порушення цілісності кісткової тканини нижньої щелепи в ділянці великих кутніх зубів за допомогою стоматологічного бора. Операцію проводили під тіопенталовим наркозом. Опіоїдну залежність моделювали шляхом щоденного (1 раз на добу в однаковий проміжок часу) введення наркотичного анальгетика налбуфіну. Налбуфін вводили внутрішньом'язово за схемою: 1-ий тиждень - 8 мг/кг, 2-ий тиждень - 15 мг/кг, 3-ий тиждень -20 мг/кг, 4-ий тиждень - 25 мг/кг, 5-ий тиждень - 30 мг/кг, 6-ий тиждень - 35 мг/кг. Контроль якості кісткової тканини нижньої щелепи в ділянці нанесення травми здійснювали з використанням дентального радіовізіографа фірми Siemens з програмним забезпеченням Trophy Radiology. За одиницю виміру щільності тканин брали умовну одиницю сірості (УОС). Дослідження якості кісткової тканини нижньої щелепи проводили через 1, 2 і 3 тижні після нанесення травми інтактним щурам та щурам, яким попередньо впродовж трьох тижнів вводили налбуфін і продовжували його введення ще протягом трьох тижнів після травми, а також тваринам без травми, які перебували на різних термінах опіоїдної залежності (по 5 тварин на кожному терміні експерименту). Ще 35 тварин сформували контрольну групу. Для кожної групи визначали середнє арифметичне значення досліджуваного показника, дисперсію та довірчий інтервал при рівні достовірності $\mathrm{P}=95 \%$. Результати. Проведений аналіз щільності кісткової тканини нижньої щелепи впродовж трьох тижнів після нанесення кісткоруйнуючої травми інтактним тваринам дав змогу встановити наявність вираженої динаміки досліджуваного показника. Упродовж двох тижнів після нанесення травми щільність кісткової тканини нижньої щелепи у травмованій ділянці поступово зростає, збільшуючись до кінця другого тижня удвічі порівняно з нормою. Упродовж третього тижня досліджуваний показник знижується, але залишається дещо вищим, ніж у інтактних тварин. Для з'ясування особливостей зміни щільності кісткової тканини на тлі тривалого вживання налбуфіну, нами простежено динаміку досліджуваного показника впродовж 6 тижнів введення препарату та після його відміни. Проведений аналіз засвідчив, що впродовж двох тижнів вживання налбуфіну щільність кісткової тканини нижньої щелепи поступово зростала у порівняно з контролем, а впродовж третього тижня знижувалась, повертаючись практично до нормальних показників. Упродовж четвертого та п’ятого тижнів досліджуваний показник знову зростав, а на шостому тижні знижувався, залишаючись без змін і впродовж тижня після відміни препарату. Оскільки щільність кісткової тканини нижньої щелепи після трьох тижнів введення налбуфіну максимально наближена до нормальних показників, саме цей термін нами обрано для нанесення кісткоруйнуючої травми тваринам, яким моделювали налбуфінову (опіоїдну) залежність. Аналіз отриманих даних засвідчив, що динаміка щільності кісткової тканини після кісткоруйнуючої травми на тлі вживання налбуфіну є зовсім іншою, ніж у інтактних тварин. Через тиждень після нанесеної травми досліджуваний показник практично не змінюється, через два

Клінічна анатомія та оперативна хірурхія - Т. 18, № 1 - 2019

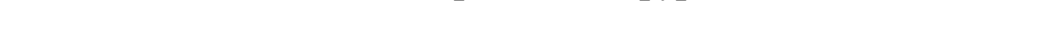


тижні дещо зростає, і збільшення його продовжується до кінця експерименту. Висновки: Нанесення кісткоруйнуючої травми призводить до вираженої динаміки щільності кісткової тканини у ділянці травми, що засвідчує про зміну їі якості. Динаміка щільності кісткової тканини нижньої щелепи після кісткоруйнуючої травми на тлі вживання налбуфіну є іншою, ніж у інтактних тварин. Через три тижні після нанесення кісткоруйнуючої травми щільність кісткової тканини у інтактних щурів лише незначно перевищує норму, тоді як у тварин з опіоїдною залежністю досліджуваний показник удвічі перевищує норму.

Ключові слова: кісткова тканина, нижня щелепа, щільність, налбуфін, опіоїдна залежність.

Травми щелеп належать до групи найчастіших причин звернень пацієнтів у клініку травматології та щелепно-лицевої хірургії [1-5]. Дані сучасної наукової літератури, що грунтуються на результатах численних клінічних та експериментальних досліджень, засвідчують, що перебіг репаративного остеогенезу зумовлений різними чинниками: віком пацієнта, наявністю супутніх чи фонових патологій, впливу навколишнього середовища та контакту з токсичними речовинами [3, 6-16]. Важливим чинником, що впливає як на стан організму в цілому, так і на структуру, якість та механічні властивості кісткової тканини є тривалий вплив на організм наркотичних речовин [17-19]. Універсальним показником, що дозволяе 3'ясувати якість кісткової тканини, оцінити і спрогнозувати ранні кількісно-якісні зміни при різноманітних патологічних станах, простежити їх динаміку в клінічних і експериментальних умовах, $\epsilon$ показник щільності, визначити який дають змогу сучасні методи променевої діагностики комп'ютерна томографія, дентальна радіовізіографія $[6,13,20]$.

Мета дослідження: 3'ясувати закономірності посттравматичної динаміки щільності кісткової тканини нижньої щелепи після нанесення кісткоруйнуючої травми інтактним тваринам та тваринам, які впродовж тривалого часу вживають налбуфін.

Матеріал іметоди. Дослідження виконане на 20 статевозрілих безпородних щурах-самиях масою тіла 180-200 г та віком 3,5 місяиі. Дослідних тварин утримували в умовах віварію Львівського начіонального медичного університету імені Данила Галицького. Усі дослідження проводилися згідно з положенями Свропейської конвенщії щодо захисту хребетних тварин, яких використовують в експериментальних та інших наукових иілях (Страсбург, 1986), Директиви Ради Свропи 86/609/EEC (1986), Закону Украӥни № 3447-IV «Про захист тварин від жорстокого поводження».

Травму моделювали шляхом порушення иілісності кісткової тканини нижньої щелепи в діляниі великих кутніх зубів за допомогою стомато- логічного бора. Операцію проводили під тіопенталовим наркозом [21].

Опіоїдну залежність моделювали шляхом щоденного (1 раз на добу в однаковий проміжок часу) введення наркотичного анальгетика налбуфіну. Налбуфін вводили внутрішньом'язово за схемою: 1-ий тиждень - 8 мг/кг, 2-ий тиждень 15 мг/кг, 3-ий тиждень - 20 мг/кг, 4-ий тиждень - 25 мг/кг, 5-ий тиждень - 30 мг/кг, 6-ий тиждень - 35 мг/кг [22].

Контроль якості кісткової тканини нижньої щелепи в ділянці нанесення травми здійснювали 3 використанням дентального радіовізіографа фiрми Siemens з програмним забезпеченням Trophy Radiology. За одиницю виміру щілььності тканин брали умовну одиницю сірості (УОС).

Дослідження якості кісткової тканини нижньої щелепи проводили через 1, 2 і 3 тижні після нанесення травми інтактним шурам та щурам, яким попередньо впродовж трьох тижнів вводили налбуфін і продовжували його введення ще протягом трьох тижнів після травми, а також тваринам без травми, які перебували на різних термінах опіоїдної залежності (по 5 тварин на кожному терміні експерименту). Ще з 5 тварин сформували контрольну групу.

Для кожної групи визначали середнє арифметичне значення досліджуваного показника, дисперсію та довірчий інтервал при рівні достовірності $P=95 \%$.

Дослідження є частиною планової наукової роботи кафедр нормальної анатомї та оперативної хірургії з топографічною анатомією «Структурна організаиія, ангіоархітектоніка та антропометричні особливості органів у внутрішньо- та позаутробному періодах розвитку, за умов екзо- та ендопатогенних факторів», номер державної реєстраuіï: 0115U000041, яка виконується у Львівському начіональному медичному університеті імені Данила Галицького згідно з державним планом та програмою впродовж 2015-2020 років.

На проведення дослідження отримано дозвіл комісії з питань етики Львівського національного медичного університету імені Данила Галицького (протокол № 3 від 16 березня 2015 р.). 
Результати дослідження та їх обговорення. Проведений аналіз щільності кісткової тканини нижньої щелепи впродовж трьох тижнів після нанесення кісткоруйнуючої травми інтактним тваринам дозволив встановити наявність вираженої динаміки досліджуваного показника (табл. 1).

Отримані дані засвідчують, що впродовж двох тижнів після нанесення травми щільність кісткової тканини нижньої щелепи у травмованій ділянці поступово зростає, збільшуючись до кінця другого тижня удвічі порівняно з нормою. Упродовж третього тижня після нанесення травми досліджуваний показник знижується, але залишається дещо вищим, ніж у інтактних тварин (рис. 1).

Для з'ясування особливостей зміни щільності кісткової тканини на тлі тривалого вживання налбуфіну, нами простежено динаміку досліджуваного показника впродовж 6 тижнів введення препарату та після його відміни (табл. 2).

Аналіз динаміки досліджуваного показника засвідчив, що продовж двох тижнів вживання налбуфіну щільність кісткової тканини нижньої щелепи поступово зростала порівняно 3 контролем, а впродовж третього тижня знижувалась, повертаючись практично до нормальних показників. Упродовж четвертого та п'ятого тижнів досліджуваний показник знову зростав, а на шостому тижні знижувався, залишаючись без змін і впродовж тижня після відміни препарату (рис. 2). Оскільки щільність кісткової тканини нижньої щелепи після трьох тижнів введення налбуфін максимально наближена до нормальних показни

Таблиия 1

Динаміка показників щільності кісткової тканини нижньої щелепи щур
нанесення кісткоруйнуючої травми
\begin{tabular}{|l|c|c|c|c|c|}
\hline & $\mathrm{M}$ & Дисп & $\Delta$ & $\mathrm{M}-\Delta$ & $\mathrm{M}+\Delta$ \\
\hline контроль & 75,33 & 177,87 & 14 & 61,34 & 89,33 \\
\hline 1 тиждень після травми & 107,67 & 689,87 & 27,56 & 80,1 & 135,23 \\
\hline 2 тиждень після травми & 152 & 394,8 & 20,85 & 131,15 & 172,85 \\
\hline 3 тиждень після травми & 99,5 & 820,7 & 30,06 & 69,44 & 129,56 \\
\hline
\end{tabular}

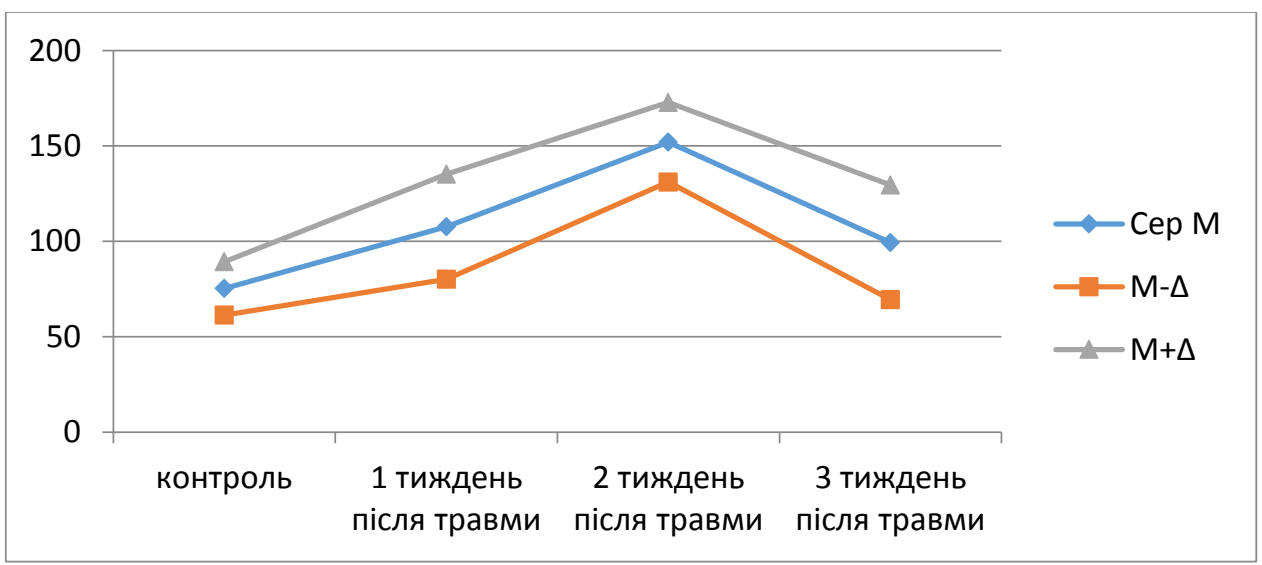

Рис. 1. Динаміка показників щільності кісткової тканини нижньої щелепи щура впродовж трьох тижнів після нанесення кісткоруйнуючої травми

Динаміка показників щільності кісткової тканини нижньої щелепи щура на тлі вживання налбуфіну

\begin{tabular}{|l|l|l|l|l|l|}
\hline & $\mathrm{M}$ & Дисп & $\Delta$ & $\mathrm{M}-\Delta$ & $\mathrm{M}+\Delta$ \\
\hline інтактна тварина & 75,33 & 177,87 & 14 & 61,34 & 89,33 \\
\hline 1-й тиждень експерименту & 78,17 & 191,77 & 14,53 & 63,63 & 92,7 \\
\hline 2-й тиждень експерименту & 85,67 & 809,47 & 29,86 & 55,81 & 115,52 \\
\hline 3-й тиждень експерименту & 75,5 & 333,1 & 19,15 & 56,35 & 94,65 \\
\hline 4-й тиждень експерименту & 82,33 & 433,07 & 21,84 & 60,49 & 104,17 \\
\hline 5-й тиждень експерименту & 83,17 & 380,97 & 20,48 & 62,68 & 103,65 \\
\hline 6-й тиждень експерименту & 79,5 & 537,5 & 24,33 & 55,17 & 103,83 \\
\hline відміна & 79,5 & 420,7 & 21,52 & 57,98 & 101,02 \\
\hline
\end{tabular}


ків, саме цей термін нами обрано для нанесення кісткоруйнуючої травми тваринам, яким моделювали налбуфінову (опіоїдну) залежність.

Аналіз отриманих даних засвідчив, що динаміка щільності кісткової тканини після кісткоруйнуючої травми на тлі вживання налбуфіну $є$ зовсім іншою, ніж у інтактних тварин. Через тиж- день після нанесеної травми досліджуваний показник практично не змінюється, через два тижні дещо зростає, і збільшення його продовжується до кінця експерименту: через 3 тижні після нанесення травми щільність кісткової тканини на тлі вживання налбуфіну майже удвічі вища, ніж у інтактних тварин (табл. 3 , рис. 3 ).

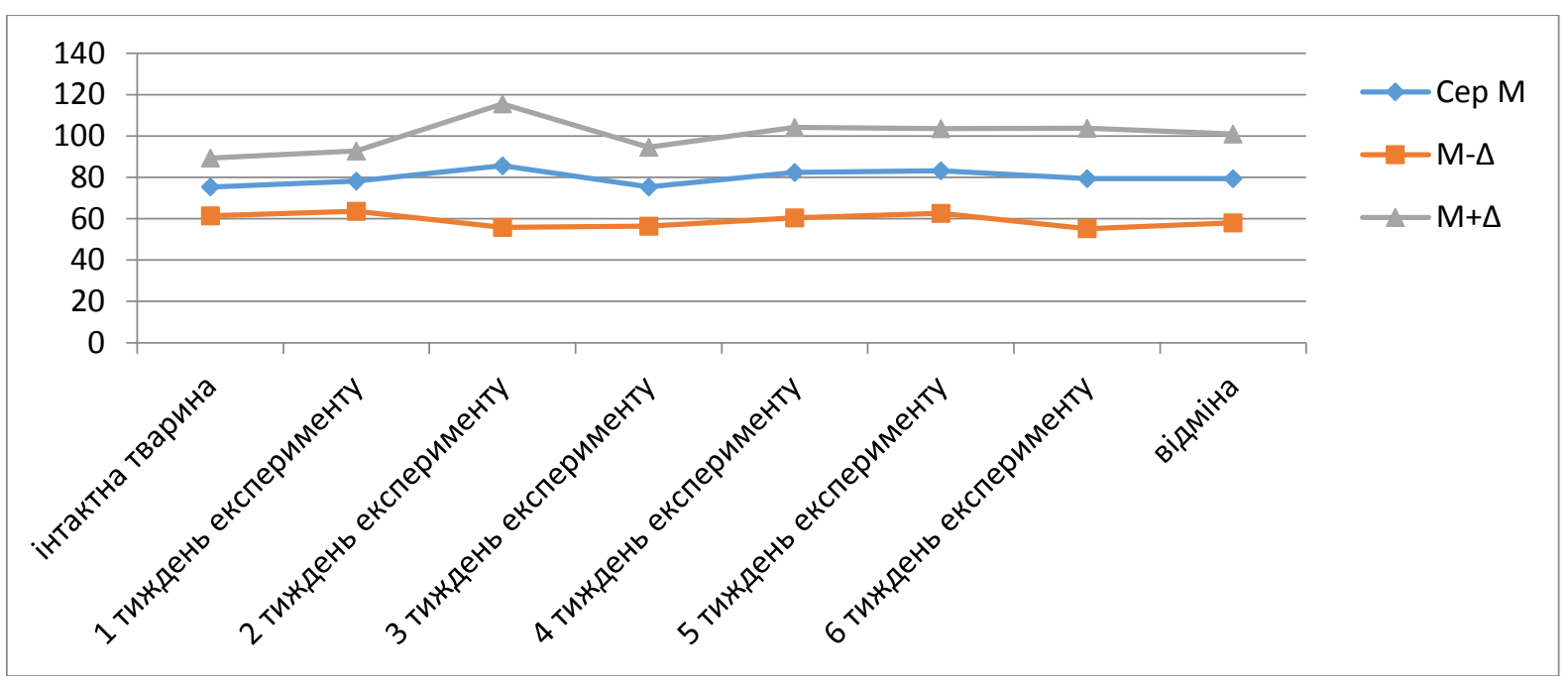

Рис. 2. Динаміка показників щุільності кісткової тканини нижньої щелели щура на тлі шеститижевого вживання налбуфіну

Таблиця 3

Динаміка показників щільності кісткової тканини нижньої щелепи щура після нанесеної кісткоруйнуючої травми на тлі вживання налбуфіну

\begin{tabular}{|l|c|c|c|c|c|}
\hline \multicolumn{1}{|c|}{ контроль } & $\mathrm{M}$ & Дисп & $\Delta$ & $\mathrm{M}-\Delta$ & $\mathrm{M}+\Delta$ \\
\hline $\begin{array}{l}\text { 3-й тиждень вживання налбуфіну / перед нанесен- } \\
\text { ням травми }\end{array}$ & 75,33 & 177,87 & 14 & 61,34 & 89,33 \\
\hline $\begin{array}{l}\text { 4-й тиждень вживання налбуфіну / 1-й тиждень пі- } \\
\text { сля травми }\end{array}$ & 74,5 & 421,1 & 21,54 & 52,96 & 96,04 \\
\hline $\begin{array}{l}\text { 5-й тиждень вживання налбуфіну / 2-й тижні після } \\
\text { травми }\end{array}$ & 86 & 1128,4 & 35,25 & 50,75 & 121,25 \\
\hline $\begin{array}{l}\text { 6-й тиждень вживання налбуфіну / 3-й тиждень пі- } \\
\text { сля травми }\end{array}$ & 133,5 & 3108,3 & 58,51 & 74,99 & 192,01 \\
\hline
\end{tabular}

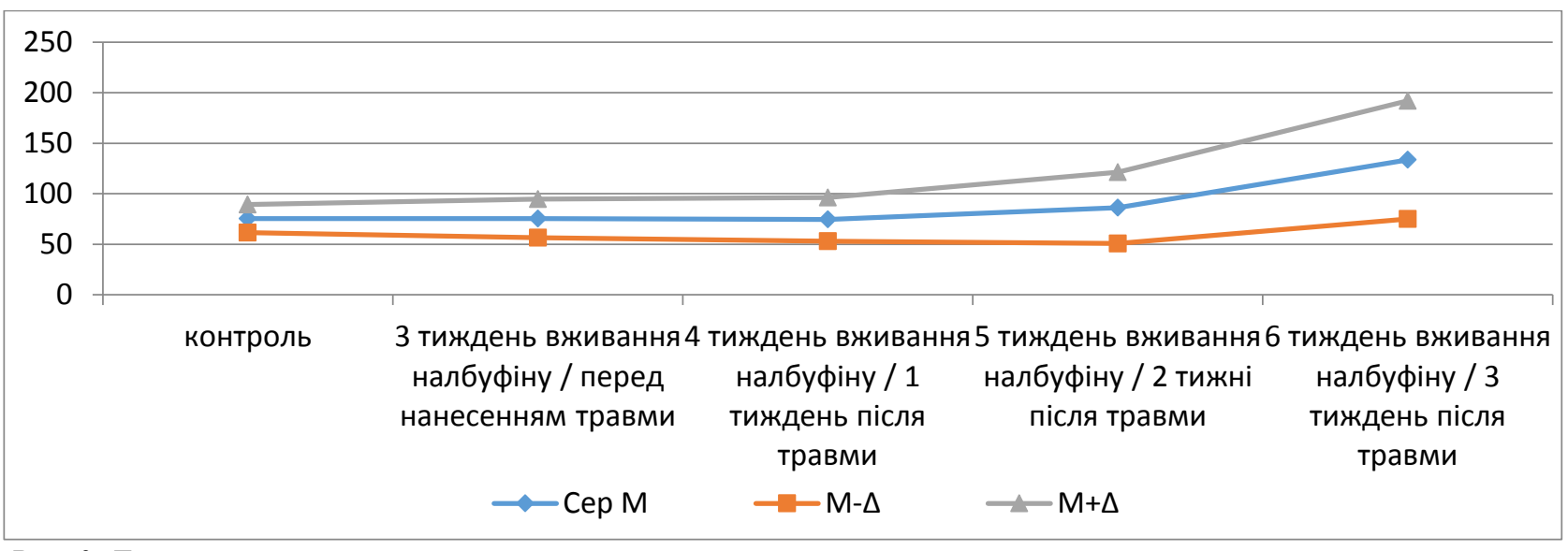

Рис. 3. Динаміка показників щзільності кісткової тканини нижньої щзелепи щура після нанесеної кісткоруйнуючої травми на тлі вживання налбуфіну 
Порівняння динаміки щільності кісткової тканини нижньої щелепи щура після кісткоруйнуючої травми, нанесеної інтактним тваринам та на фоні тривалого вживання налбуфіну, засвідчує значну різницю досліджуваного показника у тва- рин різних груп упродовж усього експерименту. При цьому через один і два тижні після нанесення травми щільність кісткової тканини є вищою в інтактних тварин, а через три тижні - у тварин, що вживали налбуфін (рис. 4).

п травма травма на тлі вживання налбуфіну

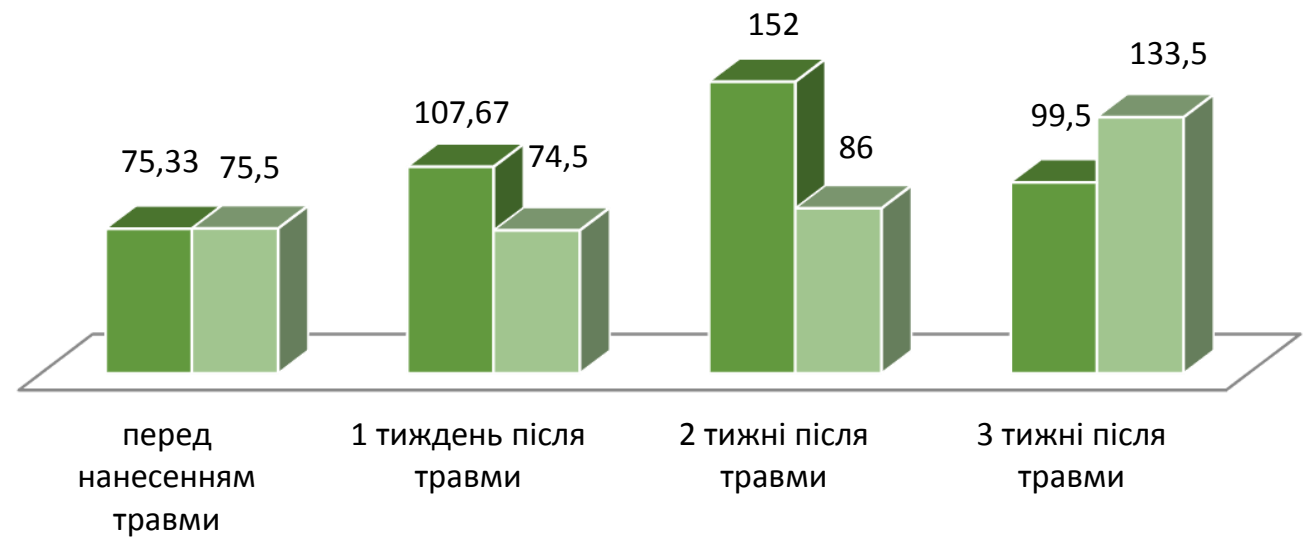

Рис. 4. Порівняння динаміки показників щуіль

ності кісткової тканини нижньої щелепи щура після кісткоруйнуючої травми, нанесеної інтактним тваринам та на тлі тривалого вживання налбуфіну

Висновки. 1. Нанесення кісткоруйнуючої травми призводить до вираженої динаміки щільності кісткової тканини у ділянці травми, що засвідчує про зміну їі якості. 2. Динаміка щільності кісткової тканини нижньої щелепи після кісткоруйнуючої травми на тлі вживання налбуфіну є іншою, ніж у інтактних тварин. 3. Через три тижні після нанесення кісткоруйнуючої травми щільність кісткової тканини в інтактних щурів лише незначно перевищує норму, тоді як у тварин з опіоїдною за- лежністю досліджуваний показник удвічі перевищує норму.

Перспективи подальших досліджень. Результати досліджень, присвячених вивченню щільності кісткової тканини різних частин скелета людини та дослідних тварин в нормі з врахуванням вікових та гендерних особливостей, а також з'ясування динаміки змін даного показника під дією ендо- та екзогенних чинників можуть стати теоретичним підгрунтям для розпрацювання критеріїв ранньої діагностики патологічних змін у кістковій тканині обстежуваних осіб та оптимізації вибору способів їх корекції.

\section{Список використаної літератури}

1. Аветіков ДС, Локес КП, Ставииький СО, Яиенко IB, Розколупа ОО. Переломи нижньої щелепи:аналіз частоти виникнення, локалізаиї та ускладнень. Вісник проблем біології і медицини. 2014;3(3):62-4. 2. Рибачук АВ, Мамонов РО, Маланчук ВО. Епідеміологія травматичних переломів нижньої щелепи в період з 2005 по 2014 р. за матеріалами клініки кафедри. Харківська хірургічна школа. 2016;1:117-22. 3. Федірко ГВ. Сучасне уявлення про механізм регенерачії нижньої щелепи в умовах політравми. Клінічна стоматологія. 2015;1:89-94.

4. Mingzhe L, Xiaofeng X, Bing X. Current therapy of atrophic edentulous mandibular fractures among elderly people. Hua Xi Kou Qiang Yi Xue Za Zhi. 2017;35(4):433-6. doi: 10.7518/hxkq.2017.04.017.

5. Pichardo SEC, Ten Broek FW, Richard van Merkesteyn JP. Treatment of pathologic fractures of the mandible in stage III medication-related osteonecrosis of the jaw-an observational study. J Craniomaxillofac Surg. 2018;46(8):1241-6. doi: 10.1016/j.jcms.2018.05.025.

6. Carmo JZB, Medeiros SF. Mandibular Inferior Cortex Erosion on Dental Panoramic Radiograph as a Sign of Low Bone Mineral Density in Postmenopausal Women. Rev Bras Ginecol Obstet. 2017;39(12):663-9. doi: 10.1055/s-0037-1606622.

7. Dahy K, Takahashi K, Saito K, Kiso H, Rezk I, Oga T, et al. Gender differences in morphological and functional outcomes after mandibular setback surgery. J Craniomaxillofac Surg. 2018;46(6):887-92. doi: 10.1016/j.jcms.2018.04.006.

8. Damanaki A, Memmert S, Nokhbehsaim M, Sanyal A, Gnad T, Pfeifer A, et al. Impact of obesity and aging 
on crestal alveolar bone height in mice. Ann Anat. 2018;218:227-35. doi: 10.1016/j.aanat.2018.04.005. 9. Huang D, Wu Q, Zhou X, Kang F. Activity and morphologic changes in the mandible after mandibular osteotomy. Am J Orthod Dentofacial Orthop. 2019;155(1):40-7. doi: 10.1016/j.ajodo.2018.02.016.

10. Jategaonkar AA, Badhey AK, Sokoya M, Kadakia S, Mudrovich S, Ducic Y. Total mandibulectomy defect in the setting of chronic bisphosphonate use. Am J Otolaryngol. 2018;39(5):649-51. doi: 10.1016/j.amjoto.2018.05.004.

11. Kim JW, Tatad JCI, Landayan MEA, Kim SJ, Kim MR. Animal model for medication-related osteonecrosis of the jaw with precedent metabolic bone disease. Bone. 2015;81:442-8. doi: 10.1016/j.bone.2015.08.012.

12. Kim TG, Chung KJ, Lee JH, Kim YH, Lee JH. Clinical Outcomes Between Atrophic and Nonatrophic Mandibular Fracture in Elderly Patients. J Craniofac Surg. 2018;29(8):e815-e818. doi: 10.1097/SCS.0000000000004863.

13. On SW, Kim HJ, Kim J, Choi JW, Jung YW, Song SI. Effect of Osteoporosis on Bone Density of Orthognathic Osteotomy Sites in Maxillofacial Region. J Craniofac Surg. 2016;27(7):e678-e683.

14. Yoshioka Y, Yamachika E, Nakanishi M, Ninomiya T, Nakatsuji K, Kobayashi Y, et al. Cathepsin K inhibitor causes changes in crystallinity and crystal structure of newly-formed mandibular bone in rats. Br J Oral Maxillofac Surg. 2018;56(8):732-8. doi: 10.1016/j.bjoms.2018.08.003.

15. Yoshioka Y, Yamachika E, Nakanishi M, Ninomiya T, Nakatsuji K, Matsubara M, et al. Molecular alterations of newly formed mandibular bone caused by zoledronate. Int J Oral Maxillofac Surg. 2018;47(9):1206-13. doi: 10.1016/j.ijom.2018.02.002.

16. Zandi M, Dehghan A, Amini P, Rezaeian L, Doulati S. Evaluation of mandibular fracture healing in rats under zoledronate therapy: A histologic study. Injury. 2017;48(12):2683-7. doi: 10.1016/j.injury.2017.10.026. 17. Ferguson BL, Lieblich SE, Dodson TB. Third Molar Extraction and Persistent Use of Opioids. JAMA. 2018;320(22):2377. doi: 10.1001/jama.2018.17187.

18. Iero PT, Mulherin DR, Jensen O, Berry T, Danesi H, Razook SJ. A Prospective, Randomized, Open-Label Study Comparing an Opioid-Sparing Postsurgical Pain Management Protocol With and Without Liposomal Bupivacaine for Full-Arch Implant Surgery. Int J Oral Maxillofac Implants. 2018;33(5):1155-64. doi: 10.11607/jomi.5938.

19. Poghosyan YM, Hakobyan KA, Poghosyan AY, Avetisyan EK. Surgical treatment of jaw osteonecrosis in "Krokodil» drug addicted patients. J Craniomaxillofac Surg. 2014;42(8):1639-43. doi: 10.1016/j.jcms.2014.05.005.

20. Рижук Х, Кухлевський Ю, Масна 3. Особливості щуільності твердих тканин зубошелепного апарату у осіб юнацького віку, щуо проживають на Львівщчні. Вісник проблем біологї $і$ медицини. 2011;3(1):138-40.

21. Согуйко РР, Масна 33, Билинь ГВ, винахідники; Львівський національний медичний університет імені Данила Галицького, патентовласник. Спосіб моделювання травми нижньої щелепи щура. Патент на корисну модель №118784. 2017 Серп 28.

22. Онисько РМ, Пальтов СВ, Фік ВБ, Вільхова ІВ, Кривко ЮЯ, Якимів НЯ, винахідники; Львівський національний медичний університет імені Данила Галицького, патентовласник. Спосіб моделювання фізичної опіоїдної залежності у щурів. Патент України № 76564. 2013 Січ 10.

\section{References}

1. Avetikov DS, Lokes KP, Stavyts'kyy SO, Yatsenko IV, Rozkolupa OO. Perelomy nyzhn'oyi shchelepy: analiz chasto vynyknennya, lokalizatsiyi ta uskladnennya. Visnyk problem biolohiyi i medytsyny. 2014;3(3):62-4. (in Ukrainian).

2. Rybachuk AV, Mamonov RO, Malanchuk VO. Epidemiolohiya travmatychnykh perelomiv nyzhn'oyi shchilyny v period z 2005 po 2014 r. za materialamy kliniky kafedry. Kharkivs'ka khirurhichna shkola. 2016;1:117-22. (in Ukrainian).

3. Fedirko HV. Suchasne uyavlennya pro mekhanizm reheneratsiyi nyzhn'oyi shchelepy v politravmi. Klinichna stomatolohiya. 2015;1:89-94. (in Ukrainian).

4. Mingzhe L, Xiaofeng X, Bing X. Current therapy of atrophic edentulous mandibular fractures among elderly people. Hua Xi Kou Qiang Yi Xue Za Zhi. 2017;35(4):433-6. doi: 10.7518/hxkq.2017.04.017.

5. Pichardo SEC, Ten Broek FW, Richard van Merkesteyn JP. Treatment of pathologic fractures of the mandible in stage III medication-related osteonecrosis of the jaw-an observational study. J Craniomaxillofac Surg. 2018;46(8):1241-6. doi: 10.1016/j.jcms.2018.05.025.

6. Carmo JZB, Medeiros SF. Mandibular Inferior Cortex Erosion on Dental Panoramic Radiograph as a Sign of Low Bone Mineral Density in Postmenopausal Women. Rev Bras Ginecol Obstet. 2017;39(12):663-9. doi: 10.1055/s-0037-1606622.

7. Dahy K, Takahashi K, Saito K, Kiso H, Rezk I, Oga T, et al. Gender differences in morphological and 
functional outcomes after mandibular setback surgery. J Craniomaxillofac Surg. 2018;46(6):887-92. doi: 10.1016/j.jcms.2018.04.006.

8. Damanaki A, Memmert S, Nokhbehsaim M, Sanyal A, Gnad T, Pfeifer A, et al. Impact of obesity and aging on crestal alveolar bone height in mice. Ann Anat. 2018;218:227-35. doi: 10.1016/j.aanat.2018.04.005.

9. Huang D, Wu Q, Zhou X, Kang F. Activity and morphologic changes in the mandible after mandibular osteotomy. Am J Orthod Dentofacial Orthop. 2019;155(1):40-7. doi: 10.1016/j.ajodo.2018.02.016.

10. Jategaonkar AA, Badhey AK, Sokoya M, Kadakia S, Mudrovich S, Ducic Y. Total mandibulectomy defect in the setting of chronic bisphosphonate use. Am J Otolaryngol. 2018;39(5):649-51. doi: 10.1016/j.amjoto.2018.05.004.

11. Kim JW, Tatad JCI, Landayan MEA, Kim SJ, Kim MR. Animal model for medication-related osteonecrosis of the jaw with precedent metabolic bone disease. Bone. 2015;81:442-8. doi: 10.1016/j.bone.2015.08.012.

12. Kim TG, Chung KJ, Lee JH, Kim YH, Lee JH. Clinical Outcomes Between Atrophic and Nonatrophic Mandibular Fracture in Elderly Patients. J Craniofac Surg. 2018;29(8):e815-e818. doi: 10.1097/SCS.0000000000004863.

13. On SW, Kim HJ, Kim J, Choi JW, Jung YW, Song SI. Effect of Osteoporosis on Bone Density of Orthognathic Osteotomy Sites in Maxillofacial Region. J Craniofac Surg. 2016;27(7):e678-e683.

14. Yoshioka Y, Yamachika E, Nakanishi M, Ninomiya T, Nakatsuji K, Kobayashi Y, et al. Cathepsin K inhibitor causes changes in crystallinity and crystal structure of newly-formed mandibular bone in rats. Br J Oral Maxillofac Surg. 2018;56(8):732-8. doi: 10.1016/j.bjoms.2018.08.003.

15. Yoshioka Y, Yamachika E, Nakanishi M, Ninomiya T, Nakatsuji K, Matsubara M, et al. Molecular alterations of newly formed mandibular bone caused by zoledronate. Int J Oral Maxillofac Surg. 2018;47(9):1206-13. doi: 10.1016/j.ijom.2018.02.002.

16. Zandi M, Dehghan A, Amini P, Rezaeian L, Doulati S. Evaluation of mandibular fracture healing in rats under zoledronate therapy: A histologic study. Injury. 2017;48(12):2683-7. doi: 10.1016/j.injury.2017.10.026.

17. Ferguson BL, Lieblich SE, Dodson TB. Third Molar Extraction and Persistent Use of Opioids. JAMA. 2018;320(22):2377. doi: 10.1001/jama.2018.17187.

18. Iero PT, Mulherin DR, Jensen O, Berry T, Danesi H, Razook SJ. A Prospective, Randomized, Open-Label Study Comparing an Opioid-Sparing Postsurgical Pain Management Protocol With and Without Liposomal Bupivacaine for Full-Arch Implant Surgery. Int J Oral Maxillofac Implants. 2018;33(5):1155-64. doi: 10.11607/jomi.5938.

19. Poghosyan YM, Hakobyan KA, Poghosyan AY, Avetisyan EK. Surgical treatment of jaw osteonecrosis in «Krokodil» drug addicted patients. $J$ Craniomaxillofac Surg. 2014;42(8):1639-43. doi: 10.1016/j.jcms.2014.05.005.

20. Ryzhuk X, Kukhlevs'kyy YU., Masna Z. Osoblyvosti shchil'nosti tverdykh tkanyn zuboshchelepnoho aparatu $u$ osib yunats'koho viku, shcho prozhyvayut' na L'vivshchyni. Visnyk problem biolohiyi $i$ medytsyny. 2011;3(1):138-40. (in Ukrainian).

21. Sohuyko RR, Masna ZZ, Bilin' HV, vynakhidnyky; Danyla Halyts'koho, patentovlasnyk. Zaokhochennya modelyuvannya travmy nyzhn'oyi shchil'nosti shchury. Patent na korysnu model' №118784. 2017 Serp 28. (in Ukrainian).

22. Onysko RM, Pal'tov YEV, Fik VB, Vil'khova IV, Kryvko YUYA, Yakymiv NYA, vynakhidnyky; Danyla Halyts'koho, patentovlasnyk. Revolyutsiynyy modelyuvannya fizychnoyi opioyidnoyi yim u shchuriv. Patent Ukrayiny № 76564. 2013 Sich 10. (in Ukrainian).

\section{СРАВНЕНИЕ ПОСТТРАВМАТИЧЕСКОЙ ДИНАМИКИ ПЛОТНОСТИ КОСТНОЙ ТКАНИ НИЖНЕЙ ЧЕЛЮСТИ У ИНТАКТНЫХ КРЫС И НА ФОНЕ ДЛИТЕЛЬНОГО УПОТРЕБЛЕ- НИЯ НАЛБУФИНА}

Резюме. Плотность костной ткани является универсальным показателем, позволяющим определить ее качество, оценить и спрогнозировать ранние количественно-качественные изменения и проследить динамику в клинических и экспериментальных условиях. Целью нашего исследования стало выяснение закономерностей посттравматической динамики плотности костной ткани нижней челюсти после нанесения костноразрушающей травмы интактным животным и животным, которые на протяжении длительного времени употребляли налбуфин. Исследование выполнено на 20 половозрелых беспородных крысах-самцах массой тела 180-200 г и возрастом 3,5 месяца. Подопытных животных содержали в условиях вивария Львовского национального медицинского университета имени Даниила Галицкого. Все исследования проводились в соответствии с положениями Европейской конвенции по защите позвоночных животных, используемых в экспериментальных и других научных целях (Страсбург, 1986), Директивы Совета Европы 86/609 / EЕC (1986), Закона Украины № 3447-IV «О защите животных от 
жестокого обращения». Травму моделировали путем нарушения целостности костной ткани нижней челюсти в области больших коренных зубов с помощью стоматологического бора. Операцию проводили под тиопенталовым наркозом. Опиоидную зависимость моделировали путем ежедневного (1 раз в сутки в одинаковый промежуток времени) введение наркотического анальгетика налбуфина. Налбуфин вводили внутримышечно по схеме: первая неделя -8 мг / кг, вторая неделя - 15 мг / кг, третья неделя - 20 мг / кг, четвёртая неделя - 25 мг / кг, пятая неделя - 30 мг / кг, шестая неделя - 35 мг / кг. Контроль качества костной ткани нижней челюсти в области нанесения травмы осуществляли с использованием дентального радиовизиографа фирмы Siemens с программным обеспечением Trophy Radiology. За единицу измерения плотности тканей брали условную единицу серости (УЕС). Исследование качества костной ткани нижней челюсти проводили через 1, 2 и 3 недели после нанесения травмы интактным крысам и крысам, которым предварительно в течение трех недель вводили налбуфин и продолжали его введение еще в течение трех недель после травмы, а также животным без травмы, которые находились на разных терминах опиоидной зависимости (по 5 животных на каждом этапе эксперимента). Еще с 5 животных сформировали контрольную группу. Для каждой группы определяли среднее арифметическое значение исследуемого показателя, дисперсию и доверительный интервал при уровне достоверности $\mathrm{P}=95 \%$. Результаты. Проведенный анализ плотности костной ткани нижней челюсти в течение трех недель после нанесения костноразрушающей травмы интактным животным позволил установить наличие выраженной динамики исследуемого показателя. В течение двух недель после нанесения травмы плотность костной ткани нижней челюсти в травмированной области постепенно растет, увеличиваясь к концу второй недели в два раза по сравнению с нормой. В течение третьей недели исследуемый показатель снижается, но остается несколько выше, чем у интактных животных. Для выяснения особенностей изменения плотности костной ткани на фоне длительного употребления налбуфина, нами прослежена динамика исследуемого показателя в течение 6 недель введения препарата и после его отмены. Проведенный анализ показал, что в течение двух недель употребления налбуфина плотность костной ткани нижней челюсти постепенно росла в сравнении с контролем, а в течение третьей недели снижалась, возвращаясь практически до нормальных показателей. В течение четвертого и пятого недель исследуемый показатель снова рос, а на шестой неделе снижался, оставаясь без изменений и в течение недели после отмены препарата. Поскольку плотность костной ткани нижней челюсти после трех недель введения налбуфина максимально приближена к нормальным показателям, именно этот срок нами выбран для нанесения костноразрушающей травмы животным, которым моделировали налбуфинову (опиоидной) зависимость. Анализ полученных данных показал, что динамика плотности костной ткани после костноразрушающей травмы на фоне употребления налбуфина совсем другая, чем у интактных животных. Через неделю после нанесенной травмы исследуемый показатель практически не меняется, две недели несколько возрастает, и увеличение его продолжается до конца эксперимента. Выводы: Нанесение костноразрушающей травмы приводит к выраженной динамики плотности костной ткани в области травмы, свидетельствует об изменении ее качества. Динамика плотности костной ткани нижней челюсти после костноразрушающей травмы на фоне употребления налбуфина иная, чем у интактных животных. Через три недели после нанесения костноразрушающей травмы плотность костной ткани у интактных крыс лишь незначительно превышает норму, тогда как у животных с опиоидной зависимостью исследуемый показатель вдвое превышает норму.

Ключевые слова: костная ткань, нижняя челюсть, плотность, налбуфин, опиоидной зависимостью.

\section{COMPARISON OF THE POSTTRUMMATIC DYNAMICS OF THE BONE TISSUE DENSITY OF THE LOWER JAW IN THE INTACT RATS AND ON THE BACKGROUND OF THE PERMANENT NALBUFINE USE}

Abstract. The research is part of the planned scientific work of the departments of normal anatomy and operative surgery with topographical anatomy "Structural organization, angioarchitectonics and anthropometric features of organs in the internal and extrauterine periods of development, under conditions of exo-endopathogenic factors", the state registration number: 0115U000041, which is executed in Danylo Halytsky Lviv National Medical University according to the state plan and program during 2015-2020. The permission of the Ethics Committee of the Danylo Halytsky Lviv National Medical University (protocol No. 3 dated March 16, 2015) was obtained for the study. Actuality. Bone tissue density is a universal indicator that allows to determine its quality, estimate and predict early quantitative and qualitative changes and trace their dynamics in clinical and experimental conditions. The aim of our study was to find out the regularities of the post-traumatic dynamics of the density of the mandibular bone tissue after performing a bone-destroying injury to intact animals and animals that have been taking nalbuphine for a long time. The study was performed on 20 sexually mature, male rats with a body weight of 180-200 $\mathrm{g}$ and a 3.5-month old age. Experimental animals were kept in the 
vivarium of the Danylo Halytsky Lviv National Medical Universit. All studies were conducted in accordance with the provisions of the European Convention for the protection of vertebrate animals used for experimental and other scientific purposes (Strasbourg, 1986), Council Directive 86/609 / EEC (1986), Law of Ukraine No. 3447-IV "On the Protection of Animals from Cruel handling". The injury was modeled by breaking the integrity of the bony tissue of the mandible in the area of mokars with the help of dental drill. The operation was performed under thiopental anesthesia. Opioid dependence was modeled by a daily (once a day at the same time interval) injection of a narcotic analgetic Nalbuphine. Nalbuphine was injected intramuscularly according to the following schedule: 1 week $-8 \mathrm{mg} / \mathrm{kg}, 2$ nd week $-15 \mathrm{mg} / \mathrm{kg}, 3 \mathrm{rd}$ week $-20 \mathrm{mg} / \mathrm{kg}$, 4th week -25 $\mathrm{mg} / \mathrm{kg}, 5$-this week $-30 \mathrm{mg} / \mathrm{kg}$, 6th week $-35 \mathrm{mg} / \mathrm{kg}$. Control of the quality of bone tissue of the mandible in the area of injury was carried out using a dental radiosignographer Siemens with the software Trophy Radiology. The unit of measurement of tissue density was taken to be the conventional unit of gravity (CUG). The quality of mandibular bone tissue was studied in 1,2 and 3 weeks after injury to intact rats and rats, who had been injected nalbuphine for up to three weeks and continued to receive it for another three weeks after the injury, as well as non-traumatic animals present at different terms of opioid dependence (5 animals per experiment period). Another 5 animals were in the control group. For each group, the arithmetic mean value of the researched indicator, the variance and the confidence interval at the level of reliability of $\mathrm{P}=95 \%$ were determined. Results. An analysis of the density of bone tissue of the mandible within three weeks after the applicationof the trauma which leads to the bone loss in intact animals made it possible to establish the presence of an expressed dynamics of the investigated indicator. Within two weeks after injury, the density of bone tissue of the mandible in the injured area gradually increases, increasing by the end of the second week twice as much as the norm. During the third week, the investigated parameter is declining, but remains somewhat higher than in intact animals. To determine the peculiarities of changes in the density of bone tissue on the background of prolonged nalbuphine use, the dynamics of the studied parameters for 6 weeks of administration and after its discontinuation was studied. The analysis showed that after two weeks of use of nalbuphine, the density of mandibular bone tissue gradually increased compared to control group, and during the third week it decreased, returning to almost normal values. During the fourth and fifth weeks, the researched parameter increased again, and decreased in the sixth week, remaining unchanged and within a week after discontinuation of the drug. Since the density of the bone tissue of the mandible after three weeks of administration of nalbuphina is as close to normal as possible, this is the term that was selected to perform bone injury on animals that were modeled on nalbuphine (opioid) dependence. The analysis of the data showed that the dynamics of bone density after a bone injury with the use of nalbuphine is quite different from that of intact animals. A week after the trauma, the investigated parameter practically does not change, after two week increases and its rise continues until the end of the experiment. Conclusion. The application of a bone-traumatic injury leads to an expressed dynamics of bone density in the area of the trauma, which testifies a change in its quality. The dynamics of bone density of the mandible after a bone injury with the use of nalbuphine is different from that of intact animals. Three weeks after bone injuries, bone density in intact rats only slightly exceeds the norm, while in animals with opioid dependence, the investigated parameter is twice as high as normal.

Key words: bone tissue, mandible, density, nalbuphine, opioid dependence.

\section{Відомості про автора:}

Согуйко Ростислав Романович - асистент кафедри оперативної хірургії з топографічною анатомією Львівського національного медичного університету імені Данила Галицького;

Information about author:

Sohuyko Rostyslav R. - Assistant Professor of the Departmen of Operative Surgery and Topographic Anatomy Danylo Halytsky Lviv National Medical University.

Надійшла 22.01.2019 p.

Рецензент - проф. Слободян О.М (Чернівці) 